\title{
Penggunaan Media Audio Visual untuk Meningkatkan Kemampuan Mengenal Huruf Pada Anak Usia Dini di RA Amanah Amaliyah
}

\author{
${ }^{1}$ Khadijah \\ Universitas Islam Negeri Sumatera Utara \\ email: khadijah@uinsu.ac.id \\ ${ }^{2}$ Arlina \\ Universitas Islam Negeri Sumatera Utara \\ email: arlina@uinsu.ac.id \\ ${ }^{3}$ Rizka Amalia Rahmadani \\ Universitas Islam Negeri Sumatera Utara \\ email: rizkaamalia892@gmail.com
}

$\begin{array}{llll}\text { Article received } & : \text { : } 10 \text { Oktober } 2020 & \text { Review process } & : 28 \text { Desember } 2020 \\ \text { Article accepted } & : 5 \text { Januari } 2021 & \text { Article published } & : 8 \text { Maret } 2021\end{array}$

\begin{abstract}
Abstrak
Kemampuan mengenal huruf merupakan pondasi atau kemampuan awal di bidang bahasa dan keaksaraan yang harus dimiliki anak agar dapat memahami informasi dalam bentuk tulisan. Namun hasil observasi awal di RA Amanah Amaliyah menunjukkan bahwa kemampuan mengenal huruf anak usia dini belum semuanya berkembang optimal. Oleh karena itu, penelitian ini menggunakan media audio visual untuk meningkatkan kemampuan mengenal huruf pada anak usia dini. Penelitian ini berjenis penelitian tindakan kelas (PTK) desain Kurt Lewin melalui empat tahapan dan dua siklus. Subjek pada penelitian ini yaitu anak usia 4-5 tahun. Instrumen penelitian yang digunakan yaitu pedoman wawancara dan lembar observasi. Hasil penelitian menunjukkan bahwa pembelajaran pada siklus I sebanyak 13 orang $(65 \%)$ yang tuntas dalam pembelajaran dengan nilai rata-rata 15,05 dan pada siklus II terjadi peningkatan sebanyak 20 orang $(100 \%)$ tuntas dalam pembelajaran dengan nilai rata-rata 23,6. Pada penelitian ini juga ditemukan bahwa anak lebih semangat dan antusias dalam mengikuti pembelajaran karena media audio visual mendukung anak berperan aktif dalam proses pembelajaran dan menarik perhatian anak.

Kata Kunci : Kemampuan mengenal huruf; Media audio visual; Bahasa; Raudhatul athfal
\end{abstract}

\begin{abstract}
The ability to recognize letters is the foundation or initial ability in the field of language and literacy that children must have in order to understand information in written form. However, the results of preliminary observations at $R A$ Amanah Amaliyah indicate that the ability to recognize early childhood letters has not all developed optimally. Therefore, this study uses audio-visual media to improve the ability to recognize letters in early childhood. This research is a classroom action research $(C A R)$ designed by Kurt Lewin through four stages and two cycles. The subjects in this study were children aged 4-5 years. The research instruments used were interview guidelines and observation sheets. The results showed that learning in cycle I as many as 13 people (65\%) completed the learning with an average value of 15.05 and in cycle II there was an increase of 20 people (100\%) who completed learning with an average value of 23, 6. In this study, it was also found that children were more enthusiastic and enthusiastic in participating in learning because
\end{abstract}

Penggunaan Media Audio Visual untuk Meningkatkan Kemampuan Mengenal Huruf Pada Anak Usia Dini di RA Amanah Amaliyah Copyright (c) 2021 Khadijah, Arlina, Rahmadani 
http://jurnaltarbiyah.uinsu.ac.id/index.php/raudhah

e-mail: jurnalraudhah@uinsu.ac.id

p-ISSN: 2338-2163

e-ISSN: 2716-2435

audio-visual media supported children to play an active role in the learning process and attract children's attention.

Keywords: Ability to recognize letters; Audio visual media; Language; Raudhatul athfal

\section{A. PENDAHULUAN}

Anak mempunyai beberapa hak di dalam kehidupannya seperti hak untuk bermain, beristirahat, berinteraksi, belajar dan mendapatkan pendidikan yang layak. Karena belajar dan pendidikan merupakan hak bagi setiap anak bangsa di Indonesia maka setiap orang tua mempunyai kewajiban untuk memberikan hak tersebut, dan pemerintah turut andil membuat kebijakan dan menyediakan sarana prasarana pendidikan yang memadai. Hasil penelitian Osborn, White dan Bloom dalam (Cahyani, 2019) menyatakan bahwa perkembangan intelektual anak pada usia 0-4 tahun mencapai 50\%, 0-8 tahun mencapai 80\% dan 0-18 tahun mencapai 100\%. Menurut (Maisarah, 2019) pada usia 0-8 tahun perkembangan otak anak dapat mencapai $80 \%$, sehingga jika anak diberikan stimulus yang dapat merangsang otak maka neuron yang ada dalam otak akan berkembang atau bercabang-cabang sehingga anak menjadi lebih cerdas. Namun pengalaman yang diperoleh anak akan menetap jika digunakan secara terus-menerus dan akan menyusut jika tidak digunakan. Dengan demikian, pendidikan sangat penting bagi anak usia dini namun tetap mengikuti karakteristik siswa.

Anak usia dini mempunyai karakteristik rasa ingin tahu yang tinggi dan belajar melalui bermain atau kegiatan yang menyenangkan. Sehingga pendidikan yang diberikan pada anak usia dini harus menyenangkan, kondusif, memotivasi anak untuk suka belajar, membina karakter baik pada diri anak, dan menghindari tindakan kekerasan. Aspek perkembangan yang perlu ditingkatkan pada diri anak yaitu: nilai agama dan moral, motorik, sosial emosional, kognitif, dan bahasa. Salah satu tingkat pencapaian perkembangan bahasa yang sangat penting bagi anak usia dini adalah mengenal huruf. Kemampuan mengenal huruf menjadi pondasi bagi perkembangan bahasa pada anak usia dini, khususnya anak usia 4-5 tahun sebagai tingkatan terendah di dalam kelompok belajar PAUD/ TK/ RA/ sederajat.

Hal ini penting sekali karena mengenal huruf merupakan pengetahuan dasar bagi anak untuk mampu mengenal tulisan dan kata yang ada disekitarnya. Kemampuan

Penggunaan Media Audio Visual untuk Meningkatkan Kemampuan Mengenal Huruf Pada Anak Usia Dini di RA Amanah Amaliyah Copyright (c) 2021 Khadijah, Arlina, Rahmadani 
http://jurnaltarbiyah.uinsu.ac.id/index.php/raudhah

e-mail: jurnalraudhah@uinsu.ac.id

p-ISSN: 2338-2163

e-ISSN: $2716-2435$

mengenal huruf juga merupakan kemampuan yang sangat penting untuk dimiliki anak karena menjadi kemampuan awal yang mendukung perkembangan bahasa dan keaksaraan. Karena pengenalan huruf merupakan hal baru bagi anak usia dini, maka guru membutuhkan media yang mendukung proses pembelajaran agar materi yang disampaikan benar-benar nyata. Menurut (Arsyad, 2000), salah satu media yang layak untuk digunakan yaitu media audio visual. Media audio visual merupakan jenis media yang selain mengandung unsur suara juga mengandung unsur gambar yang bisa dilihat, misalnya rekaman video, berbagai ukuran film, slide, suara, dan lain sebagainya. Kemampuan media ini dianggap lebih menarik, sebab mengandung kedua unsur jenis media yang pertama dan kedua. Penelitian (Fujiyanto et al., 2016) membuktikan bahwa penggunaan media audio visual dapat meningkatkan hasil belajar siswa pada materi mengenal makhluk hidup. Penggunaan media audio visual melibatkan berbagai indera, seperti: telinga (audio) dan mata (visual) yang memungkinkan pesan mudah dimengerti, bahkan terdapat juga media audio visual yang dirancang untuk mengajak anak melatih motorik kasarnya melalui tarian atau gerakan yang sesuai untuk anak usia dini. Dengan demikian, pengenalan huruf pada anak usia dini dapat dilakukan menggunakan media audio visual.

Namun kenyataan yang ditemukan di RA Amanah Amaliyah bahwa pembelajaran masih menggunakan cara lama yaitu pengenalan huruf melalui lembar kerja anak, di sekolah belum pernah menggunakan media audio visual dan seringnya menggunakan papan tulis dan spidol untuk mengenalkan huruf pada anak. Hal tersebut menyebabkan anak hanya fokus untuk menyelesaikan tugas di dalam lembar kerja anak, dan hanya sedikit yang mampu mengenal huruf tersebut. Dari hasil observasi awal diperoleh bahwa sebagian besar anak belum mengenal semua huruf alfabet, hanya 6 dari 20 anak yang mampu mengenal huruf dengan baik, sebanyak 14 dari 20 anak terlihat kesulitan dan kebingungan untuk menyebutkan huruf-hurufnya. Beberapa anak juga terbalik saat menyebutkan huruf dengan lafal ataupun bentuknya mirip, antara lain $d$ dan $b, f$ dan $v, m$ dan $n, p$ dan $b, m$ dan w. Anak juga kesulitan saat diminta menyebutkan kata dari sebuah huruf, begitu pula sebaliknya saat diminta untuk menyebutkan huruf depan dari sebuah kata. Faktor yang mempengaruhi anak yang belum optimal pada kemampuan mengenal huruf disebabkan karena kemampuan pada diri anak yang belum matang sehingga 
http://jurnaltarbiyah.uinsu.ac.id/index.php/raudhah

e-mail: jurnalraudhah@uinsu.ac.id

p-ISSN: 2338-2163

e-ISSN: $2716-2435$

hasilnya belum optimal. Guru sangat berperan dalam mengenalkan huruf kepada anak dan sebaiknya guru harus memperhatikan faktor dominan yang dapat mempengaruhi pengenalan huruf seperti penggunaan media pembelajaran yang mendukung atau didesain khusus untuk mengenalkan huruf pada anak usia 4-5 tahun. Media pembelajaran yang digunakan pada penelitian ini yaitu media audio-visual.

\section{B. METODE PENELITIAN}

Penelitian ini dilakukan di RA Amanah Amaliyah di kecamatan air batu tahun ajaran 2019/2020. Penelitian ini berjenis penelitian tindakan kelas (PTK) desain model Kurt Lewin. Menurut (Direktorat, 1999; Lewin, 1990; Madeamin, 2012; Maisarah, 2020), prosedur PTK pada desain model Lewin terdiri dari empat langkah, yaitu: planning, acting, observing, and reflecting. Keempat langkah tersebut disebut dengan siklus, sehingga pelaksanaan PTK biasanya terdiri dari 2 (dua) siklus atau lebih. Pada penelitian ini dilaksanakan PTK sebanyak 2 (dua) siklus karena pada siklus kedua telah terbukti peningkatan yang mencapai kriteria PKK $80 \%$.

Subjek dalam penelitian ini yaitu seluruh anak usia 4-5 tahun di RA Amanah Amaliyah sebanyak 20 orang anak pada satu kelas. Objek yang diteliti yaitu media audio visual dan kemampuan mengenal huruf. Data tentang kemampuan mengenal huruf diperoleh menggunakan instrumen lembar observasi, rubrik penilaian dan studi dokumen. Teknik analisis data yang digunakan yaitu analisis data kuantitatif dan analisis data kualitatif.

\section{HASIL TEMUAN DAN PEMBAHASAN}

\section{Pra Siklus}

Pada kegiatan pra siklus dilakukan observasi awal terhadap proses pengenalan huruf di kelompok A untuk anak usia 4-5 tahun di RA Amanah Amaliyah. Kemudian diberikan pretes untuk memperoleh data mengenai kemampuan awal yang dimiliki anak mengenai pengenalan huruf. Hasil observasi pra siklus kemampuan mengenal huruf anak usia 4-5 tahun di RA Amanah Amaliyah terdapat pada tabel 1:

Penggunaan Media Audio Visual untuk Meningkatkan Kemampuan Mengenal Huruf Pada Anak Usia Dini di RA Amanah Amaliyah Copyright (c) 2021 Khadijah, Arlina, Rahmadani 
Tabel 1. Kemampuan Mengenal Huruf Anak Pada Pra Siklus

\begin{tabular}{|c|c|c|c|c|}
\hline No. & Tingkat Perkembangan & Tingkat Ketuntasan & Jumlah anak & Persentase \\
\hline 1. & BSB dan BSH & Tuntas & 6 & $30 \%$ \\
\hline 2. & BB dan MB & Tidak Tuntas & 14 & $70 \%$ \\
\hline \multicolumn{2}{|r|}{ Jumlah } & $\mathbf{2 0}$ & $\mathbf{1 0 0} \%$ \\
\hline
\end{tabular}

Dari ketuntasan klasikal yang diperoleh anak pada tes awal hanya sebanyak $30 \%$ atau 6 orang yang tuntas dalam menjawab tes yang diberikan, sementara itu $70 \%$ atau 14 orang lainnya tidak tuntas dalam menjawab tes yang diberikan. Ini membuktikan bahwa hasil belajar anak pada mengenal huruf masih sangat rendah dan ketuntasan hasil belajar anak secara klasikal belum tercapai.

\section{Siklus I}

a) Perencanaan

Pada tahap perencanaan peneliti menyiapkan dan merancang Rancangan Perencanaan Pembelajaran Harian (RPPH) dengan materi mengenal huruf dengan tema rekreasi, menyiapkan media pembelajaran berupa video untuk menjadi sarana dalam pembelajaran yang dilakukan pada siklus I.

b) Pelaksanaan

Pada proses pelaksanaan belajar daring ini tentrtunya diharapkan dapat menjauhkan anak dari kemungkinan terpapar virus korona, walaupun dengan kondisi saat pandemi sekolah tetap menjalankan proses belajarnya melalui online via Whatsapp. Kegiatan Awal pelaksanaan peneliti dilakukan pada tanggal 13 juli 2020 dimulainya dengan merencanakan konten sesuai unit pembelajaran. Kemudian peneliti merangkai kegiatan pembelajaran online dalam mengenalkan huruf pada anak, pembelajaran dengan konten online salah satu yang peneliti lakukan berupa video yang sudah dipersiapkan oleh peneliti dan diunggah melalui ke grub kelas melalui via Whatsapp dengan tema mengenalkan huruf abjad dan penelitipun mengucapkan salam di awal pembelajaran dan kemudian anak menjawab salam dan membaca doa secara bersama- sama yang dibimbing oleh peneliti, kemudian peneliti menanyakan kabar anak dan peneliti juga memberikan motivasi dan arahan kepada anak 
http://jurnaltarbiyah.uinsu.ac.id/index.php/raudhah

e-mail: jurnalraudhah@uinsu.ac.id

p-ISSN: 2338-2163

e-ISSN: 2716-2435

yang berujuan untuk menarik perhatian anak agar lebih berkonsentrasi dalam proses pembelajaran, Kemudian mengenalkan aturan bermain atau pelaksanaan pembelajaran daring, pertama peneliti mengunggah video kegiatan gerak dan lagu yang mana anak diharapkan untuk mengikutinya walaupun ada beberapa anak yang merasa malas untuk mengikuti gerakan tersebut,akan tetapi peneliti tidak hanya diam saja akan tetapi lebih mengajak anak untuk mau mengikuti gerakan walau harus peneliti yang membantunya sehingga anak mau mengikuti gerakan tersebut.

Setelah masuk kegiatan inti peneliti memberikan arahan kepada anak tentang pengenalan video yang akan mereka pelajari kemudian anak mendengarkan arahan dari peneliti, pada saat itu peneliti menjelaskan bahwa tema video tersebut berisi tentang mengenal huruf abjad, setelah arahan selesai peneliti memberikan kesempatan kepada anak untuk melihat video yang peneliti unggah dengan masing-masing anak. Setelah anak selesai menonton video tersebut peneliti menanyakan apa yang diketahui anak lihat dalam video tersebut, dan masing-masing anak menjawab bahwa didalam video tersebut berisikan huruf dan disertai adanya gambar dan suara. Setelah itu peneliti memberikan tes kepada anak untuk mengetahui sejauh mana keberhasilan anak dalam mengenal huruf, peneliti menanyakan huruf apa yang mereka lihat dan bagaimana bentuk menyebutkan huruf tersebut, masing-masing anakpun menjawab dengan sesuai huruf yang ia ketahui,dan juga ada berapa anak yang diam saat ditanya peneliti mengenai huruf tersebut, setelah itu peneliti meyampaikan kepada anak agar diberi kesempatan untuk mengulanginya kembali.

Ketiga penutup, dalam kegiatan ini peneliti memberikan kesimpulan terhadap anak berdasarkan benda-benda yang ada di dalam video dan materi yang telah mereka bahas sebelumnya dan mengakhiri pembelajaran dengan memberikan nasihat tentang tetap belajar dirumah dan diakhiri dengan membaca doa bersama- sama dengan di bimbing peneliti.

c) Observasi

Pada tahap ini dilakukan observasi dan wawancara kepada guru dan siswa. Berikut hasil wawancara dengan guru:

Proses pembelajaran sudah sangat bagus dan ibu lihat anak-anak sangat antusias mengikuti pembelajaran dengan menggunakan media audio visual yang dapat menarik perhatian anak, akan tetapi masih ada ditemukan kekurangan peneliti

Penggunaan Media Audio Visual untuk Meningkatkan Kemampuan Mengenal Huruf Pada Anak Usia Dini di RA Amanah Amaliyah Copyright (c) 2021 Khadijah, Arlina, Rahmadani 
seperti dalam menyampaikan pembelajaran tersebut terlalu cepat sehingga anak-anak itu bolak- balik bertanya hingga anak-anak masih kurang fokus, jadi rizka jelaskan lagi tidak secara terburu- buru kepada anak agar anak lebih mengerti.

Pada siklus I anak merasa pembelajaran yang diberikan melalui media audio visual cukup menarik karena ada gambar dan suaranya sehingga mereka semangat belajar dan memperhatikan pembelajaran, akan tetapi ditemukan kekurangan yaitu peneliti atau guru terlalu cepat dalam menyampaikan materi, terdapat anak yang diam saat diminta untuk menyebutkan huruf, masih ada anak yang susah menunjukkan lambang huruf. hal ini dapat dilihat dari hasil wawanacara dengan tiga orang anak, yakni:

Umi videonya bagus ya mi ada banyak gambar disitu, tapi mi umi ngomongnya cepat kali tadi, jadi saya ketinggalan dan bingung (siswa pertama)

Umi susah la mi menyebutkan hurufnya mi, lupa saya mi mana huruf b mana huruf d. (siswa kedua)

Umi tadi ngomongnya kecepatan, bingung saya waktu umi suru saya menyebutkan hurufnya lagi, tapi saya senang mi disitu ada gambar mobil seperti mainan saya bahkan disitu juga ada suara juga mi. (siswa ketiga)

Berdasarkan observasi yang peneliti lakukan, peneliti menemukan dalam pelaksanaan pembelajaran peneliti merasa terlihat anak itu sangat senang dan antusias dalam mengikuti kegiatan dengan media belajaran yang peneliti buat, dan anak juga aktif saat mengikuti pembelajaran, akan tetapi ada juga anak yang diam saja pada saat disuruh mengikuti menyebutkan lambang huruf, kemudian ada juga anak yang tidak mau merespon dan juga ada anak yang melamun pada saat belajar berlangsung.

Pada saat terlaksananya pembelajaran peneliti merasa cara mengajar peneliti tidak membentak ataupun juga marah-marah dan cara penyampaian penelitipun menjelaskannya dengan cara yang mudah untuk mereka pahami, karena peneliti lihat sebagian anakpun paham apa yang telah peneliti sampaikan kepada mereka, walaupun didalam forum tersebut peneliti merasa berisik pada saat pembelajaran berlangsung sehingga kefokusan peneliti kurang konsentrasi karena lebih untuk menyarakan anak untuk tetap tenang, selebihnya peneliti juga merasa senang dengan media yang peneliti berikan dan kemauan anak yang mau mengikuti arahan peneliti.

Penggunaan Media Audio Visual untuk Meningkatkan Kemampuan Mengenal Huruf Pada Anak Usia Dini di RA Amanah Amaliyah Copyright (c) 2021 Khadijah, Arlina, Rahmadani 
http://jurnaltarbiyah.uinsu.ac.id/index.php/raudhah

e-mail: jurnalraudhah@uinsu.ac.id

p-ISSN: 2338-2163

e-ISSN: $2716-2435$

Dari data di atas menunjukkan bahwa informan memiliki beberapa pendapat yang sama tentang peneliti dan menunjukkan rasa antusias dalam proses pembelajaran dan peneliti rasa itu sangat bagus untuk mencuri perhatian anak dalam melakukan pembelajaran siklus ke I dengan harapan untuk meningkatkan hasil belajar anak yang lebih maksimal dari sebelumnya. Hasil observasi siklus I kemampuan mengenal huruf anak usia 4-5 tahun di RA Amanah Amaliyah terdapat pada tabel 2:

Tabel 2. Kemampuan Mengenal Huruf Anak Pada Siklus I

\begin{tabular}{|c|c|c|c|c|}
\hline No. & Tingkat Perkembangan & Tingkat Ketuntasan & Jumlah anak & Persentase \\
\hline 1. & BSB dan BSH & Tuntas & 13 & $65 \%$ \\
\hline 2. & BB dan MB & Tidak Tuntas & 7 & $35 \%$ \\
\hline \multicolumn{2}{|r|}{ Jumlah } & $\mathbf{2 0}$ & $\mathbf{1 0 0} \%$ \\
\hline
\end{tabular}

Dari ketuntasan klasikal yang diperoleh siswa pada siklus I sebanyak 65\% atau 13 orang yang tuntas dalam menjawab tes yang diberikan, sementara itu 35\% atau 7 orang lainnya tidak tuntas dalam menjawab tes yang diberikan. Ini membuktikan bahwa hasil belajar anak dalam mengenal huruf sangat rendah dan ketuntasan hasil belajar anak secara klasikal belum tercapai nilai KKM yang telah ditentukan.

d) Refleksi

Dari proses pelaksanaan tindakan hingga observasi ditemukan beberapa kelemahan yang terlah dijelaskan. Salah satu kelemahannya yaitu kemampuan mengenal huruf anak usia 4-5 tahun pada siklus I menggunakan media audio visual masih belum mencapai $80 \%$ tuntas KKM. Sehingga penelitian dilanjutkan pada siklus II. Kelemahan-kelemahan yang timbul pada siklus I selanjutnya diminimalisir dengan merancang pembelajaran yang lebih baik lagi pada siklus II. Perbaikan untuk siklus II yaitu:

1) Peneliti harus lebih menarik perhatian anak untuk ikut berpartisipasi secara aktif dalam proses pembelajaran.

2) Peneliti harus lebih menguasai materi dengan baik dan mampu menyampaikannya kepada anak secara sistematis dan jelas agar mudah dipahami anak.

3) Peneliti harus mampu mengalokasikan waktu dengan baik.

Penggunaan Media Audio Visual untuk Meningkatkan Kemampuan Mengenal Huruf Pada Anak Usia Dini di RA Amanah Amaliyah Copyright (c) 2021 Khadijah, Arlina, Rahmadani 
http://jurnaltarbiyah.uinsu.ac.id/index.php/raudhah

e-mail: jurnalraudhah@uinsu.ac.id

p-ISSN: 2338-2163

e-ISSN: $2716-2435$

4) Sebagian anak masih mengalami kesulitan dalam mengerjakan apa yang disuruh peneliti.

\section{Siklus II}

Adapun yang dilakukan peneliti dalam siklus II sama dengan siklus yang sebelumnya yaitu perencanaan, pelaksanaan, observasi dan refleksi. Untuk lebih jelasnya akan dijabarkan sebagai berikut:

a) Perencanaan

Pada tahap perencanaan peneliti menyiapkan dan merancang Rancangan Perencanaan Pembelajaran Harian (RPPH) dengan materi mengenal huruf. Perencanaan pada siklus II peneliti akan memperbaiki kelemahan yang di temukan pada siklus I, yaitu kelemahan pada anak dalam pelaksanaan pembelajaran terlihat dari anak itu diam saja pada saat disuruh mengikuti menyebutkan lambang huruf, kemudian ada juga anak yang tidak mau merespon dan juga ada anak yang melamun pada saat belajar berlangsung. Adapun Kelemahan pada peneliti saat pelaksanaan pembelajaran di siklus I terlihat dari peneliti terlalu cepat menjelaskan pembelajarannya dan suara kurang jelas.

b) Pelaksanaan

Dilanjutkan ke siklus II proses pelaksanaan belajar daring ini Kegiatan Awal pelaksanaan peneliti dilakukan pada tanggal 3 Agustus 2020 dimulainya dengan mengulang konten video yang sudah dipersiapkan oleh peneliti yang sebelumnya sudah diunggah ke grub kelas melalui via Whatsapp dengan tema mengenalkan huruf abjad dan penelitipun mengucapkan salam di awal pembelajaran dan kemudian anak juga menjawab salam dan setelah itu membaca doa secara bersama- sama yang dibimbing oleh peneliti, kemudian peneliti menanyakan kabar anak dan bertanya apakah suara peneliti jelas di dengar anak dan mereka menjawab kabar mereka hari ini dan menyampaikan bahwasanya suara peneliti sudah terdengar jelas dan peneliti berdiskusi siapa yang tidak hadir di forum dan peneliti juga memberikan motivasi dan arahan kepada anak yang berujuan untuk menarik perhatian anak agar lebih berkonsentrasi dalam proses pembelajaran, agar anak jangan diam atau tidak mau merespon dan tidak melamun dan diharapkan agar anak tetap tenang dan tidak berisik saat pembelajaran berlangsung, Kemudian peneliti mengenalkan

Penggunaan Media Audio Visual untuk Meningkatkan Kemampuan Mengenal Huruf Pada Anak Usia Dini di RA Amanah Amaliyah Copyright (c) 2021 Khadijah, Arlina, Rahmadani 
http://jurnaltarbiyah.uinsu.ac.id/index.php/raudhah

e-mail: jurnalraudhah@uinsu.ac.id

p-ISSN: 2338-2163

e-ISSN: $2716-2435$

aturan bermain atau pelaksanaan pembelajaran daring seperti sebelumnya yang pernah di pelajari, kemudian peneliti juga mengunggah video kegiatan gerak dan lagu yang mana anak diharapkan untuk mengikutinya lagi dan anakpun sudah mau mengikuti gerakan tersebut,akan tetapi peneliti tidak hanya diam saja akan tetapi ikut memantau anak tersebut kembali.

Setelah masuk kegiatan inti peneliti memberikan arahan kepada anak tentang mengulang video yang akan mereka pelajari kemudian anak mendengarkan arahan dari peneliti, pada saat itu peneliti menyuruh anak memutar kembali video tersebut, setelah arahan selesai peneliti memberikan kesempatan kepada anak untuk melihat video yang peneliti unggah dengan masing-masing anak. Setelah anak selesai menonton video tersebut peneliti menanyakan apa yang diketahui anak lihat dalam video tersebut, dan masing-masing anak menjawab bahwa didalam video tersebut berisikan huruf dan disertai adanya gambar dan suara. Setelah itu peneliti memberikan tes kembali kepada anak untuk mengetahui sejauh mana peningkatan anak dalam mengenal huruf, peneliti menanyakan huruf apa yang mereka ketahui dan bagaimana bentuk menyebutkan huruf tersebut, masing-masing anakpun menjawab dengan sesuai huruf yang ia ketahui. Pada pelaksanaan di siklus II anak sudah menyebutkan lambang huruf dan pengenalan huruf anaksudah meningkat.

Ketiga penutup, dalam kegiatan ini peneliti memberikan kesimpulan terhadap anak berdasarkan benda-benda yang ada di dalam video dan materi yang telah mereka bahas sebelumnya dan mengakhiri pembelajaran dengan memberikan nasihat tentang tetap belajar dirumah dan diakhiri dengan membaca doa bersama- sama dengan di bimbing peneliti.

\section{c) Observasi}

Pada tahap ini dilakukan observasi dan wawancara kepada guru dan siswa. Berikut hasil wawancara dengan guru:

Pembelajaran pada siklus II ini sudah sangat baik, ibu lihat anak-anak sudah berperan aktif dalam pembelajaran dan memahami tugas yang ananda rizka berikan. Orang tua sudah lebih berperan dalam membimbing anak selama pembelajaran berlangsung sehingga pembelajaran menjadi lebih efektif. 
Pada dasarnya banyak faktor yang mempengaruhi pembelajaran baik dari guru dan anak sesuai dengan apa yang peneliti lakukan ketika observasi terhadap anak dari informan dan memiliki karakter dan kecerdasan yang beda-beda. Adapun beberapa hal yang peneliti amati berdasarkan observasi anak sebagai berikut:

Dalam pembelajaran di siklus II ini peneliti mengamati bawasannya anak sudah mulai mengerti dalam mengenal huruf dalam pembelajaran dan mengerjakan sesuai arahan yang peneliti sampaikan kepada anak sudah mampu mengenal huruf apa yang sudah dijelaskan oleh gurunya. Hal ini dapat dilihat dari hasil wawanacara dengan tiga orang anak, yakni:

Umi,waktu saya putar videonya saya bisa bisa menyebutkannya kembali mi (siswa pertama)

Umi, saya sudah bisa mengenal huruf mi, besok kalau kita belajar lagi pake video yang lain lagi ya mi, yang baru mi, yang ada upin ipinnya umi (siswa kedua)

Umi, ada lagi gak mik video yang lain mi, video yang ini udah hapal saya umi dengan huruf-hurufnya.Umi susah la mi menyebutkan hurufnya mi, lupa saya mi mana huruf $b$ mana huruf $d$. (siswa ketiga)

Umi tadi ngomongnya kecepatan, bingung saya waktu umi suru saya menyebutkan hurufnya lagi, tapi saya senang mi disitu ada gambar mobil seperti mainan saya bahkan disitu juga ada suara juga mi. (siswa ketiga)

Setelah peneliti selesai mengamati proses belajar anak penelitipun mulai paham akan karakter yang di miliki pada diri anak. Karakter yang dimiliki anak diantaranya anak sudah berani dalam memberikan hasil menyebutkan lambang huruf, sudah mudah menerima informasi dari video, Peneliti juga mendapati banyak anak yang sudah mengerti tentang pembelajaran yang dibawakan oleh peneliti.

Dari peneliti bahwa pembelajaran di siklus II sudah lebih mudah kendala yang didapat di siklus I sudah tidak ada,dan dalam cara penyampaian penelitipun menjelaskannya dengan cara yang mudah untuk mereka pahami, karena peneliri lihat anakpun paham apa yang telah peneliti sampaikan kepada mereka. Hasil observasi siklus II kemampuan mengenal huruf anak usia 4-5 tahun di RA Amanah Amaliyah terdapat pada tabel 3:

Penggunaan Media Audio Visual untuk Meningkatkan Kemampuan Mengenal Huruf Pada Anak Usia Dini di RA Amanah Amaliyah Copyright (c) 2021 Khadijah, Arlina, Rahmadani 
Tabel 3. Kemampuan Mengenal Huruf Anak Pada Siklus II

\begin{tabular}{|c|c|c|c|c|}
\hline No. & Tingkat Perkembangan & Tingkat Ketuntasan & Jumlah anak & Persentase \\
\hline 1. & BSB dan BSH & Tuntas & 20 & $100 \%$ \\
\hline 2. & BB dan MB & Tidak Tuntas & 0 & $0 \%$ \\
\hline \multicolumn{2}{|r|}{ Jumlah } & $\mathbf{2 0}$ & $\mathbf{1 0 0} \%$ \\
\hline
\end{tabular}

Dari ketuntasan klasikal yang dipeoleh anak pada siklus II sebanyak $100 \%$ atau 20 anak yang berhasil tuntas dalam mengenal huruf dan $0 \%$ atau 0 anak belum berhasil untuk mengenal huruf yang diberikan. Dengan ini membuktikan bahwasannya media audio visual dapat meningkatkan hasil belajar anak pada tema rekreasi dalam meteri mengenal huruf.

d) Refleksi

Dari hasil siklus ke II ini di dapat hasil refleksi sebagai berikut:

1) Peneliti mampu meningkatkan hasil belajar anak pada siklus ke II

2) Peneliti mampu memperbaiki kesalahan pada siklus sebelumnya.

3) Tercapainya ketuntasan hasil belajar anak pada siklus ke II.

Pelaksanaan pembelajaran dengan menerapkan media audio visual pada siklus II telah tercapai ketuntasan belajar anak secara klasikal yaitu sebesar 100\%. Dengan demikian secara keseluruhan tujuan diadakannya penelitian tindakan kelas ini suda htercapai. Peningkatan hasil belajar anak usia 4-5 tahun pada materi mengenal huruf dengan menggunakan media audio visual di RA Amanah Amaliyah telah mencapai KKM pada siklus II, maka penelitian ini hanya sampai pada siklus II. Hal ini dapat dilihat pada gambar 1:

Penggunaan Media Audio Visual untuk Meningkatkan Kemampuan Mengenal Huruf Pada Anak Usia Dini di RA Amanah Amaliyah Copyright (c) 2021 Khadijah, Arlina, Rahmadani 
http://jurnaltarbiyah.uinsu.ac.id/index.php/raudhah

e-mail: jurnalraudhah@uinsu.ac.id

p-ISSN: 2338-2163

e-ISSN: $2716-2435$

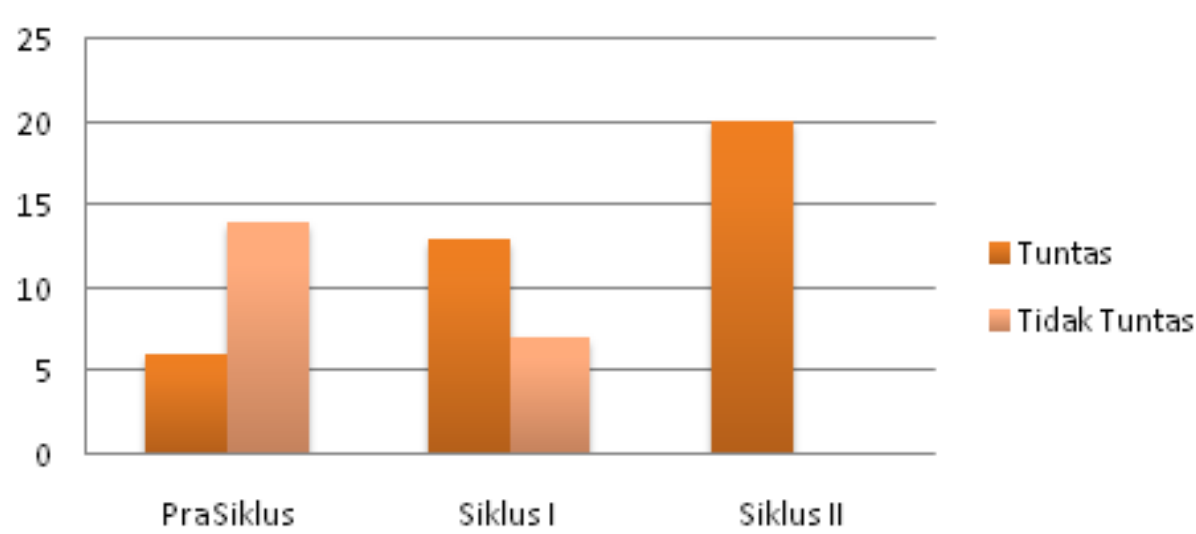

Gambar 1. Grafik Peningkatan Kemampuan Anak Mengenal Huruf 4-5 Tahun

Berdasarkan hasil pemberian post test pada siklus I diketahui bahwa ketuntasan klasikal siswa setelah melakukan pembelajaran menggunakan media audio visual pada materi mengenal huruf meningkat di bandingkan hasil belajar pre tes belajar siswa, tetapi ketuntasan klasikal siswa pada siklus I belum mencapai KKN, maka penelitian di lanjutkan ke siklus II. Hasil pemberian post test pada siklus II diketahui bahwa ketuntasan klasikal siswa setelah melakukan pembelajaran menggunakan media audio visual pada materi mengenal huruf meningkat dibandingkan hasil belajar post test pada siklus I, dan ketuntasan klasikal siswa pada siklus II sudah mencapai KKM sehingga penelitian berhenti pada siklus II dengan pembuktian bahwa penggunaan media audio visual dapat meningkatkan kemampuan mengenal huruf pada anak usia dini di RA Amanah Amaliyah.

Hasil penelitian ini juga sejalan dengan beberapa hasil penelitian yang telah dipublikasi pada jurnal, diantaranya yaitu: hasil penelitian (Oktaviani \& Kamtini, 2017) yang menyimpulkan bahwa dengan menggunakan media audiovisual memberikan pengaruh yang signifikan terhadap kemampuan membaca permulaan anak usia 5-6 tahun di TK Salsa T.A 2016/2017. Hasil penelitian (Jannah \& Hasanah, 2019) membuktikan bahwa penggunaan media audio visual berpengaruh terhadap kemampuan berbicara anak kelompok B di PAUD Terpadu Teratai UNM Makassar. Penelitian (Yanti \& Khotimah, 2019) menyatakan bahwa ada pengaruh media audio-visual terhadap kemampuan membaca huruf hijaiyah anak kelompok B di TK Al Karomah Islam Wiyung. Beberapa hasil penelitian tersebut membuktikan bahwa penggunaan media audio-visual dapat

Penggunaan Media Audio Visual untuk Meningkatkan Kemampuan Mengenal Huruf Pada Anak Usia Dini di RA Amanah Amaliyah Copyright (c) 2021 Khadijah, Arlina, Rahmadani 
http://jurnaltarbiyah.uinsu.ac.id/index.php/raudhah

e-mail: jurnalraudhah@uinsu.ac.id

p-ISSN: 2338-2163

e-ISSN: 2716-2435

mempengaruhi kebahasaan anak usia 5-6 tahun, dan yang menjadi keunikan dari penelitian ini yaitu menggunakan media audio-visual untuk meningkatkan kemampuan mengenal huruf pada anak usia 4-5 tahun.

Berdasarkan temuan penelitian terdapat peningkatan hasil belajar siswa dengan menggunakan media audio visual pada kemampuan mengenal huruf. Hal ini sesuai dengan pendapat dari Levie dan Levie dalam (Arsyad, 2000) yang mengungkapkan bahwa pemberian stimulus visual membuahkan hasil belajar lebih baik untuk tugas-tugas seperti mengingat, mengenali, dan menghubungkan-hubungkan fakta dan konsep. Pemberian stimulus verbal memberi hasil belajar yang lebih apabila pembelajaran itu melibatkan ingatan berurut-urutan. Oleh sebab itu belajar dengan menggunakan indera ganda yaitu pandang dan dengar akan memberi keuntungan bagi siswa. Siswa akan belajar lebih banyak materi yang disajikan dengan stimulus pandang dan dengar.

Fungsi utama media pembelajaran adalah sebagai alat bantu mengajar yang turut mempengaruhi iklim, kondisi, dan lingkungan belajar yang ditata dan diciptakan oleh guru. Penggunaan media pengajaran pada tahap orientasi pengajaran akan sangat membantu keefektifan proses pembelajaran dan penyampaian pesan dan isi pelajaran pada saat itu. Disamping membangkitkan motivasi dan minat peserta didik, media pembelajaran juga dapat membantu peserta didik meningkatkan pemahaman, menyajikan data dengan menarik dan terpercaya, memudahkan penafsiran data, dan memadatkan informasi.

\section{SIMPULAN DAN SARAN}

Hasil penelitian ini memperoleh beberapa simpulan, yaitu: (1) Sebelum diterapkan pembelajaran menggunakan media audio visual pada tema rekreasi dalam materi mengenal huruf hasil belajar anak masih sangat rendah. Hal ini dapat dilihat dari hasil belajar anak secara klasikal hanya 6 anak (30\%) yang tuntas dalam pembelajaran dengan nilai rata-rata 9,75. Hanya sedikit anak yang bersungguh-sungguh dalam proses pembelajaran, selebihnya banyak anak yang belum mengenal huruf. Dalam hal ini anak masih berada dibawah indikator keberhasilan dan ingin diadaknnya perubahan; dan (2) Meningkatnya hasil belajar anak setelah diterapkan media audio visul pada pembelajaran tema rekreasi materi mengenal huruf. Pembelajaran pada siklus I sebanyak 13 orang $(65 \%)$ yang tuntas dalam

Penggunaan Media Audio Visual untuk Meningkatkan Kemampuan Mengenal Huruf Pada Anak Usia Dini di RA Amanah Amaliyah 
http://jurnaltarbiyah.uinsu.ac.id/index.php/raudhah

e-mail: jurnalraudhah@uinsu.ac.id

p-ISSN: 2338-2163

e-ISSN: $2716-2435$

pembelajaran dengan nilai rata-rata 15,05 dan pada siklus II terjadi peningkatan sebanyak 20 orang $(100 \%)$ tuntas dalam pembelajaran dengan nilai rata-rata 23,6. Siswa lebih semangat dan antusias dalam mengikuti pembelajaran, karena media audio visual ini mendukung anak untuk berperan secara aktif dalam proses pembelajaran dan mendapat menarik perhatian anak.

Berdasarkan hasil penelitian tindakan maka disampaikan saran-saran sebagai berikut: (1) Penggunakan media audio visual perlu diterapkan dalam proses belajar mengajar di RA Amanah Amaliyah agar dapat meningkatkan hasil belajar peserta didik; (2) Perlu diadakannya penelitian lebih lanjut tentang pembelajaran dengan menggunakan media audio visual selain tema rekreasi materi mengenal huruf dengan tujuan peningkatan hasil belajar anak; dan (3) Kepada guru hendaknya memperhatikan kondisi belajar anak agar dapat memilih model, metode, media dan strategi yang tepat dalam pembelajaran.

\section{DAFTAR PUSTAKA}

Arsyad, A. (2000). Media Pengajaran. Jakarta: Raja Grafindo Persada.

Cahyani, A. N. (2019). Identifikasi Kemampuan Guru dalam Menerapkan Metode Proyek di TK Al-I'dad An-nuur Sleman, Yogyakarta. Jurnal Pendidikan Anak Usia Dini, $8(4)$.

Direktorat, D. (1999). Penelitian Tindakan Action Research. Jakarta: Depdiknas.

Fujiyanto, A., Jayadinata, A. K., \& Kurnia, D. (2016). Penggunaan Media Audio Visual untuk Meningkatkan Hasil Belajar Siswa Pada Materi Hubungan Antar Makhluk Hidup. Jurnal Pena Ilmiah, 1(1), 841-850.

Jannah, M., \& Hasanah, U. (2019). Pengaruh Media Pembelajaran Audio Visual Terhadap Kemampuan Berbicara Anak Kelompok B Di PAUD Terpadu Teratai UNM Makassar. Jurnal Instruksional, 1(1).

Lewin, K. (1990). Action Researchand Minority Problems the Action Research Reader. Victoria: Deakin University.

Madeamin, I. (2012). Model PTK (2): Model Lewin Menurut Elliot. Http://Www.Ishaqmadeamin.Com/2012/11/Model-Ptk-2-Model-Lewin-MenurutElliot.Html.

Penggunaan Media Audio Visual untuk Meningkatkan Kemampuan Mengenal Huruf Pada Anak Usia Dini di RA Amanah Amaliyah Copyright (c) 2021 Khadijah, Arlina, Rahmadani 
Maisarah. (2019). Matematika dan Sains Anak Usia Dini (Edisi Revisi). Medan: Akasha Sakti.

Maisarah. (2020). PTK dan Manfaatnya Bagi Guru. Bandung: Media Sains Indonesia.

Oktaviani, D., \& Kamtini. (2017). Pengaruh Penggunaan Media Audiovisual Terhadap Kemampuan Membaca Permulaan Anak Usia 5-6 Tahun di TK Salsa T.A 2016/2017. Jurnal Bunga Rampai Usia Emas, 3(1), 26-39.

Yanti, P. D., \& Khotimah, N. (2019). Pengaruh Media Audio-Visual Terhadap Kemampuan Membaca Huruf Hijaiyah Anak Kelompok B Di TK Al Karomah Islam Wiyung. Jurnal PAUD Teratai, 8(2). 